Ивлиева О.В., Шмыткова А.B.

\title{
ТЕРРИТОРИАЛЬНАЯ ОРГАНИЗАЦИЯ ТУРИСТСКОЙ ИНФРАСТРУКТУРЫ НА ЮГЕ России
}

Введение. Ц Целью исследования является анализ и обобщение данных о современном состоянии развития туристической инсрраструктуры Юга России. Представлен анализ территориальной организации средств размещения, объектов питания и транспортной инсрраструктуры региона. Обоснована значимость изучения туристской инфраструктуры на Юге России.

Материалы и методы

исследования. Исследование выполнено на основе обобщения официальных статистических данных Федеральной службы государственной статистики с использованием методов картограсрического и геоинформационного моделирования. В качестве картируемых показателей были выбраны: число мест в средствах размещения и объектах питания на душу населения, а также плотность автодорог общего пользования местного значения, находящихся в собственности муниципальных образовании.

Результаты исследований

и их обсуждение. В результате были идентифицированы наиболее «слабые места» туристской инфраструктуры в территориальном разрезе, а также выявлены «полюса роста». Представлены выводы по основным тенденциям развития коллективных средств размещения и предприятий общественного питания на Юге России; выявлены основные закономерности развития транспортного комплекса макрорегиона.

Выводы.

Реализованный на основе ГИС-технологии анализ территориальной организации туристской инсрраструктуры на Юге России позволяет идентифицировать: развитие приморских территорий как «полюсов роста»; очаговый характер локализация объектов размещения и питания на горных территориях; вовлечение в рекреационное использование территории Волго-Ахтубинской поймы; неравномерность в транспортном освоении восточных и юго-западных регионов Юга России.

Ключевые слова: Юг России, туризм, туристская инфрраструктура, средства размещения, объекты питания, транспорт. 
Ivlieva O.V., Shmytkova A.V. Southern Federal University, Rostov-on-Don, Russia annav1109@mail.ru

\section{TERRITORIAL ORGANIZATION OF TOURIST INFRASTRUCTURE IN THE SOUTH OF RUSSIA}

Introduction. The study aims to analyze and summarize data on the current status of the development of tourist infrastructure of the South of Russia. The analysis of the territorial organization of accommodation establishments, catering facilities and transport infrastructure of the region is presented. The significance of the study of tourism infrastructure in the South of Russia is substantiated.

Materials and methods. The study is based on a compilation of official statistics of the Federal State Statistics Service using cartographic and geoinformation modeling methods. The following indicators were selected as mapped indicators: the number of places in accommodation establishments and catering facilities per capita, as well as the density of public roads of local importance owned by the municipality.

Discussion of the research results.

Findings.

Keywords:
As a result, the most "weak spots" of the tourist infrastructure in the territorial aspect and the "growth poles" were identified. Conclusions are presented on the main trends in the development of collective accommodation establishments and catering facilities in the South of Russia, the main patterns of development of the transport complex of the macroregion are revealed.

The GIS-based analysis of the territorial organization of tourist infrastructure in the South of Russia allows us to identify: the development of coastal territories as "growth poles"; focal nature of the localization of accommodation and catering establishments in the mountainous territories; involvement in the recreational use of the Volga-Akhtuba floodplain; uneven transport development of the eastern and southwestern regions of southern Russia.

South of Russia, tourism, tourist infrastructure, accommodation establishments, catering establishments, transport.

\section{Введение}

Юг России, объединяющий тринадцать субъектов Российской Федерации, - устойчивая, полицентрическая, асимметричная по характеру системоформирующих связей и уровню социально-экономического развития территориальная социально-экономико-культурная система. Туристско-рекреационный комплекс имеет исключительное значение для Юга России, во многом определяет современное макроэкономическое «лицо» региона [2]. Туристская инфраструктура является один из элементов конкурентоспособности региона, а уровень ее развития во многом определяет туристскую привлекательность территории $[6 ; 7 ; 11]$.

Реализованный на основе ГИС-технологии анализ территориальной организации туристской инфраструктуры на Юге России позволяет иденти- 
фицировать приоритетные для развития туризма районы и с большой мерой научного обоснования подойти к планированию дальнейшего процесса развития туризма в макрорегионе.

\section{Материалы и методы исследования}

Исследование выполнено на основе обобщения официальных статистических данных Федеральной службы государственной статистики и анализа информационных сайтов с использованием методов картографического и геоинформационного моделирования.

\section{Результаты исследований и их обсуждение}

Основными факторами, сдерживающими рост конкурентоспособности регионов Юга России на международном рынке туристских услуг и, как результат, препятствующими реализации его туристского потенциала, является низкий уровень развития туристской инфраструктуры, в том числе недостаточность, а в ряде регионов отсутствие средств размещения туристского класса.

Сеть коллективных средств размещения на Юге России развита неравномерно и асимметрично. Более $70 \%$ всех койко-мест в коллективных средствах размещения Юга сосредоточено в Краснодарском крае (табл. 1). Кроме того, на долю Краснодарского края приходится $64 \%$ всех гостей в объектах размешения на Юге России.

В период 2010-2017 гг. число койко-мест в коллективных средствах размещения увеличилось на $72 \%$ в целом на Юге России и на $83 \%$ в Краснодарском крае.

Полученная аналитика по средствам размещения отражает резкий «отрыв» приморских зон (обретших качество «полюсов роста») от остальных субъектов России. В настоящее время российское Причерноморье - это в целом зона опережающего социально-экономического развития, притягательная для населения и инвестиций [4].

Инвестиции в основной капитал, направленные на развитие коллективных средств размещения Юга России в период с 2009 по 2017 гг, составили 157 млрд рублей, в том числе 131 млрд рублей в объекты Краснодарского края (или $83 \%$ от всего макрорегиона). Инвестиции государства и частного бизнеса в развитие гостиничной инфраструктуры Сочи в преддверии Олимпийских Игр стали основой для дальнейшего развития туристско-рекреационного комплекса Краснодарского края, повысив его значимость как «локомотива роста» туризма всего южнороссийского макрорегиона [4].

Показательно, что Ставропольский Край и республики Северного Кавказа, несмотря на уникальный природный туристский потенциал, характеризуются низкими показателями числа мест в КСР и незначительной динамикой их развития. Во всём СКФО с его горнолыжными и бальнеологическими цен- 
Таблица 1. ЧИСЛОМЕСТВКОЛЛЕКТИВНЫХСРЕДСТВАХРАЗМЕЩЕНИЯ, тыс.

Table 1. The number of bed-places in collective accommodation establishments, thousands

\begin{tabular}{|c|c|c|c|c|c|c|}
\hline & 2010 & 2013 & 2014 & 2015 & 2016 & 2017 \\
\hline Россия & 1263,2 & 1386,8 & 1573,3 & 1763,1 & 1848,1 & 2168,12 \\
\hline Юг России & 328,4 & 336,8 & 381,5 & 439,5 & 474,1 & 546,4 \\
\hline $\begin{array}{l}\text { Республика } \\
\text { Адыгея }\end{array}$ & 2,3 & 3,4 & 2,6 & 3,9 & 3,0 & 3,59 \\
\hline $\begin{array}{l}\text { Республика } \\
\text { Калмыкия }\end{array}$ & 1,5 & 0,8 & 0,8 & 0,9 & 1,0 & 1,63 \\
\hline $\begin{array}{l}\text { Краснодарский } \\
\text { край }\end{array}$ & 212,7 & 215,2 & 257,3 & 307,0 & 333,2 & 389,76 \\
\hline $\begin{array}{l}\text { Астраханская } \\
\text { область }\end{array}$ & 6,0 & 7,3 & 7,9 & 9,0 & 10,9 & 15,48 \\
\hline $\begin{array}{l}\text { Волгоградская } \\
\text { область }\end{array}$ & 16,4 & 15,6 & 16,7 & 19,4 & 21,8 & 24,09 \\
\hline $\begin{array}{l}\text { Ростовская } \\
\text { область }\end{array}$ & 24,8 & 26,5 & 27,2 & 30,1 & 31,3 & 33,60 \\
\hline $\begin{array}{l}\text { Республика } \\
\text { Дагестан }\end{array}$ & 5,5 & 5,5 & 4,7 & 5,8 & 5,5 & 6,69 \\
\hline $\begin{array}{l}\text { Республика } \\
\text { Ингушетия }\end{array}$ & 0,2 & 0,3 & 0,3 & 0,5 & 0,4 & 0,51 \\
\hline $\begin{array}{l}\text { Кабардино- } \\
\text { Балкарская } \\
\text { Республика }\end{array}$ & 12,8 & 13,3 & 13,0 & 11,9 & 10,6 & 12,21 \\
\hline $\begin{array}{l}\text { Карачаево- } \\
\text { Черкесская } \\
\text { Республика }\end{array}$ & 7,1 & 6,1 & 6,2 & 5,7 & 6,5 & 6,97 \\
\hline $\begin{array}{l}\text { Республика } \\
\text { Северная } \\
\text { Осетия - } \\
\text { Алания }\end{array}$ & 3,0 & 3,9 & 3,9 & 3,9 & 3,5 & 4,4 \\
\hline $\begin{array}{l}\text { Чеченская } \\
\text { Республика }\end{array}$ & 0,1 & 0,6 & 1,3 & 1,6 & 2,0 & 3,1 \\
\hline $\begin{array}{l}\text { Ставропольский } \\
\text { край }\end{array}$ & 36,0 & 38,4 & 39,6 & 39,7 & 44,1 & 44,5 \\
\hline
\end{tabular}


Таблица 2.

\section{МЕЖДУНАРОДНЫЕ ГОСТИНИЧНЫЕ ОПЕРАТОРЫ \\ В ГОРОДАХ ЮГА РОССИИ}

Table 2. International hotel operators in the cities of South of Russia

\begin{tabular}{l|l}
\hline Сочи & $\begin{array}{l}\text { Carlson Rezidor Hotel Group, Accor Hotels, Marriott International } \\
\text { Hilton Worldwide, Louvre Hotels Group, Rixos, Hyatt Hotels Cor- } \\
\text { poration, Four Seasons Hotels \& Resorts }\end{array}$ \\
\cline { 2 - 2 } & $\begin{array}{l}\text { Accor Hotels, Wyndham Hotel Group, Carlson Rezidor Hotel } \\
\text { Group, Marriott International }\end{array}$ \\
\hline Востов-на-Донугград & Carlson Rezidor Hotel Group, Hilton Worldwide \\
\hline Краснодар & Accor Hotels, Hilton Worldwide \\
\hline Новороссийск & Hilton Worldwide \\
\hline Геленджик & Kempinski Hotels \\
\hline Астрахань & Carlson Rezidor Hotel Group \\
\hline
\end{tabular}

трами локализовано только 78 тыс. мест в КСР, и их число выросло лишь на $20 \%$ за прошедшие восемь лет. При этом проявляется тенденция к смешению нового предложения от центра - на периферию: колоссальный рост демонстрируют субъекты с неразвитой до недавнего времени инфраструктурой размещения, например число мест в КСР в Республике Чечня возросло в 30 раз. Ведучи, всесезонный горнолыжный курорт в Чечне, принял своих первых посетителей в начале 2018 года.

Гостиничный рынок развивается не только количественно, но и качественно. На долю Сочи приходится 11\% существующего в России номерного фонда под управлением международных гостиничных операторов, таких как Carlson Rezidor Hotel Group, Accor Hotels, Marriott International Hilton Worldwide, Louvre Hotels Group, Rixos, Hyatt Hotels Corporation, Four Seasons Hotels \& Resorts (табл. 2).

Расширение географии присутствия международных гостиничных операторов часто связано со значимыми событиями мирового масштаба, такими как Олимпийские игры 2014 г. в Сочи и матчи Чемпионата мира по футболу в 2018 г. в Сочи, Волгограде и Ростове-на-Дону.

Как свидетельствует базирующийся на ГИС-технологии авторский анализ, регионы Юга России характеризуются различными показателями числа мест в гостиницах на 1000 населения (рис. 1). Определяющим фактором локализации средств размещения на Юге России выступают природные ресурсы. Наивысшая концентрация мест в средствах размещения характер- 
на для курортов Черноморского побережья Кавказа- Анапы и Геленджика (по 440 мест на 1000 человек) и Сочи (294 места на 1000 человек). Полоса Анапа - Туапсе Черноморского побережья - сухие субтропические регионы России, а полоса Туапсе-Сочи - единственные в России и самые северные в мире области влажных субтропиков. На сегодняшний день Сочи - всесезонный бальнеоклиматический курорт международного уровня, который ежегодно посещают 6 млн туристов, Анапа- преимущественно детский курорт, Геленджик - климато-бальнеологический курорт со значительными запасами лечебных минеральных вод. На долю этих трех курортов приходится половина мест в средствах размешения всего Юга России. Кроме того все большую популярность приобретают Туапсинский, Темрюкский и Ейский районы Краснодарского края.

На горных территориях локализация объектов размещения носит очаговый характер: Майкопский район в Республике Адыгея (туристский кластер «Ворота Лагонаки»), Зеленчукский район в Республике Карачаево-Черкесия (всесезонный курорт «Архыз»), Ирафский, Алагирский и Дигорский районы в Северной Осетии (Национальный парк «Алания», горнолыжный курорт «Цей»), Приэльбруский район (самая высокая гора в Европе - Эльбрус - центр горнолыжного туризма и альпинизма) и город Нальчик (бальнеологический курорт) в Кабардино-Балкарии.

На долю четырех городов Кавказских Минеральных Вод: Кисловодска, Ессентуков, Железноводска и Пятигорска приходится 39 тыс. мест (или 87\% всех койко-мест в средствах размещения Ставропольского края). Кавказские Минеральные Воды - один из старейших курортных регионов России. Свыше 130 минеральных источников и большие запасы иловой грязи озера Тамбукан (и Лысогорского озера) делают Кавказские Минеральные Воды уникальным бальнеологическим курортом.

В Ростовской области по числу мест в средствах размещения на душу населения лидирует Неклиновский район, расположенный вдоль Таганрогского залива Азовского моря. Морское побережье и благоприятный климат территории способствуют созданию на побережье сети баз отдыха и детских оздоровительных лагерей.

На севере области расположен Шолоховский район - родина великого русского писателя, лауреата нобелевской премии М.А. Шолохова, здесь сохранились быт и традиции верховых казаков, проходит международный фестиваль «Шолоховская весна», есть возможности для отдыха на Верхнем Дону. Багаевский район, расположенный на левом берегу Дона и в нижнем течении Маныча, выделяется значительными возможностями для охоты и рыбалки.

Особый регион представляет Волго-Ахтубинская пойма, расположенная в пределах трех регионов Юга России: Волгоградской и Астраханской областях и Республики Калмыкия. Живописные ландшафты, природные пар- 


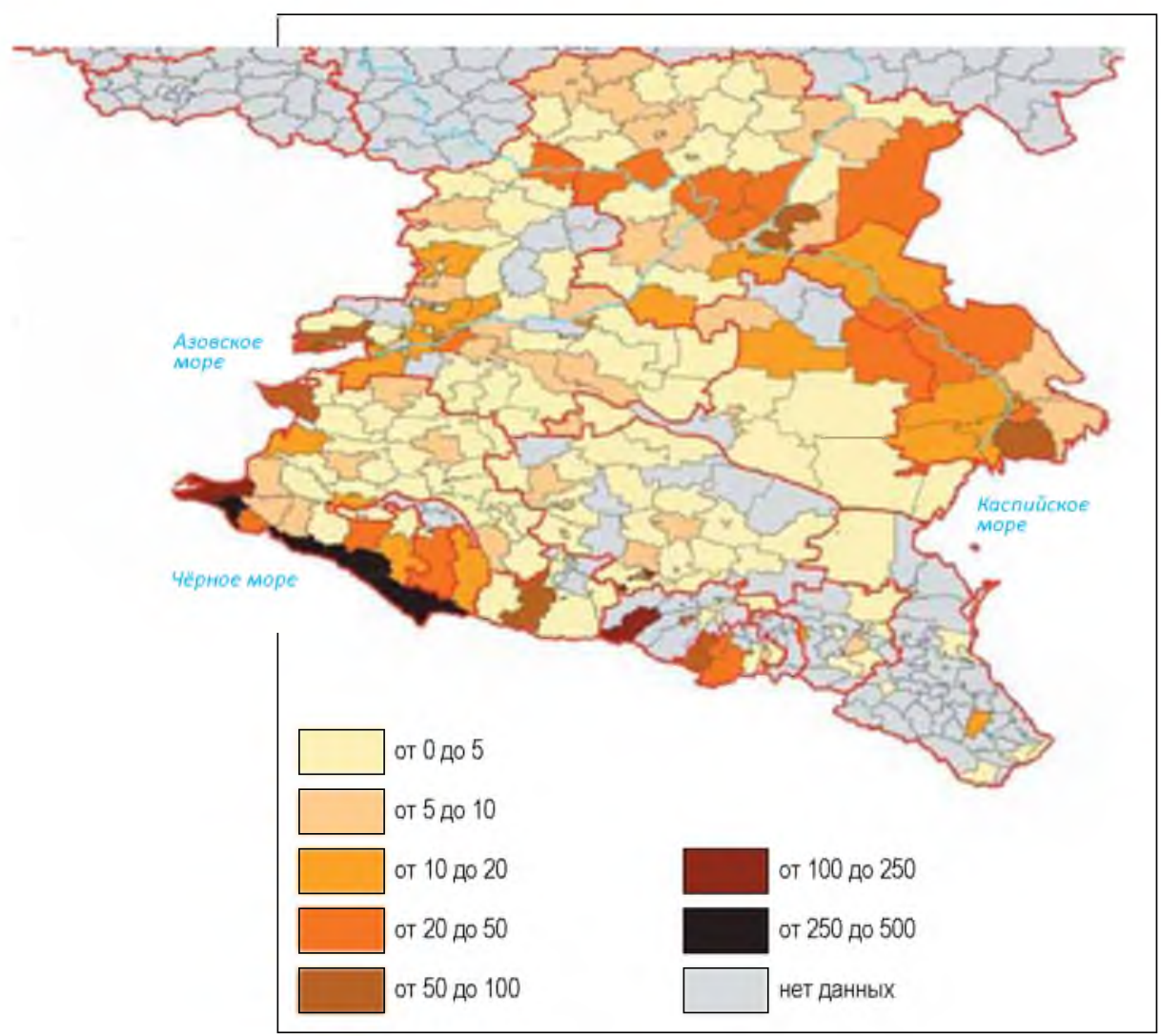

Pnc. 1.

\section{Число мест в коллективных средствах размещения} на 1000 человек населения, 2017 г.

Fig. 1 The number of bed-places in collective accommodation establishments per 1000 population, 2017.

ки, охотничьи и рыболовные хозяйства обусловили наличие большого числа баз отдыха. Наивысшие показатели по числу мест в средствах размещения имеет Среднеахтубинский район Волгоградской области - 69 мест на 1000 чел. Главными природными ценностями поймы являются: водно-болотные угодья, ключевые орнитологические территории; нерестилища ценных видов рыб, в т.ч. осетровых. На водных объектах Природного парка осуществляется любительское и спортивное рыболовство, на берегах есть места для пляжного отдыха, а водно-болотные угодья являются объектами научного туризма, дающими возможность понаблюдать в естественных условиях за водоплавающими птицами. В Астраханской области лидирует Камызякский район (51 место на 1000 человек и $14 \%$ от всех койко-мест области), занимающий основную часть дельты реки Волга и предтагающий возможности для отдыха, охоты и рыбалки. 
Наряду с объектами размещением, системообразующими в туризме выступают предприятия питания, которые могут включать рестораны, кафе, бары, общедоступные столовые, закусочные. Одним из показателей, характеризующих соответствие сети общественного питания потребностям населения, является соотношение посадочных мест к численности населения. На Юге России лидерами по числу мест на 1000 человек населения являются Республика Адыгея (75 мест), Северная Осетия - Алания и Краснодарский край (по 70 мест), в то время как наименьшие показатели (14 мест) характерны для Республик Дагестан и Ингушетия.

Как и в случае с объектами размещения, высокая концентрация мест в объектах питания на Юге России присуща территориям, обладающим значительными природными ресурсами (рис. 2). Наивысшая концентрация мест в объектах питания на 1000 человек населения характерна для курортов Краснодарского края: Геленджика (365 мест), Анапы (235) и Сочи (158), а также для районов Волго-Ахтубинской поймы. На общем фоне выделяются Мясниковский район в Ростовской области (178 мест на 1000 человек), это единственный в России район, где армяне составляют более половины населения. Село Чалтырь, в котором расположено 125 объектов питания, способных одновременно принять более 9 тыс. человек, получило название шашлычной столицы Юга России.

Роль транспорта и его влияние на развитие туризма подробно описано в литературе $[8 ; 10]$. Сдерживающим фактором роста конкурентоспособности туристско-рекреационного комплекса Юга России на межрегиональном и международном рынках является исторически сложившаяся асимметрия пространственного транспортного развития региона [1].

Средняя плотность железнодорожных путей в 2017 г. на Юге России составляла 14 км/1000 км². Симптоматично, что показатель плотности железнодорожных путей в Краснодарском крае в два раза превышал средний показатель по Югу, тогда как в Республики Калмыкия он был меньше южнороссийского в 6,5 раз.

В России Северо-Кавказский и Южный федеральные округа занимают 1 и 2 места соответственно по удельному весу автомобильных дорог с твердым покрытием в общей протяженности автомобильных дорог общего пользования. Вместе с тем регионы Юга России заметно различаются по уровню развития автомобильных дорог. Лидером по удельному весу автомобильных дорог с твердым покрытием в разрезе макрорегиона является Республика Адыгея (92,5\%), а наихудшие показатели имеют восточные регионы- Астраханская $(57,7 \%)$ и Волгоградская области $(54,6 \%)$.

Наибольшую плотность автомобильных дорог общего пользования с твердым покрытием имеют Республики Северного Кавказа: Ингушетия и Северная Осетия - Алания, тогда как в аутсайдерах: Республика Калмыкия, Астраханская и Волгоградская области. Разрыв между Республикой Ингушетия 


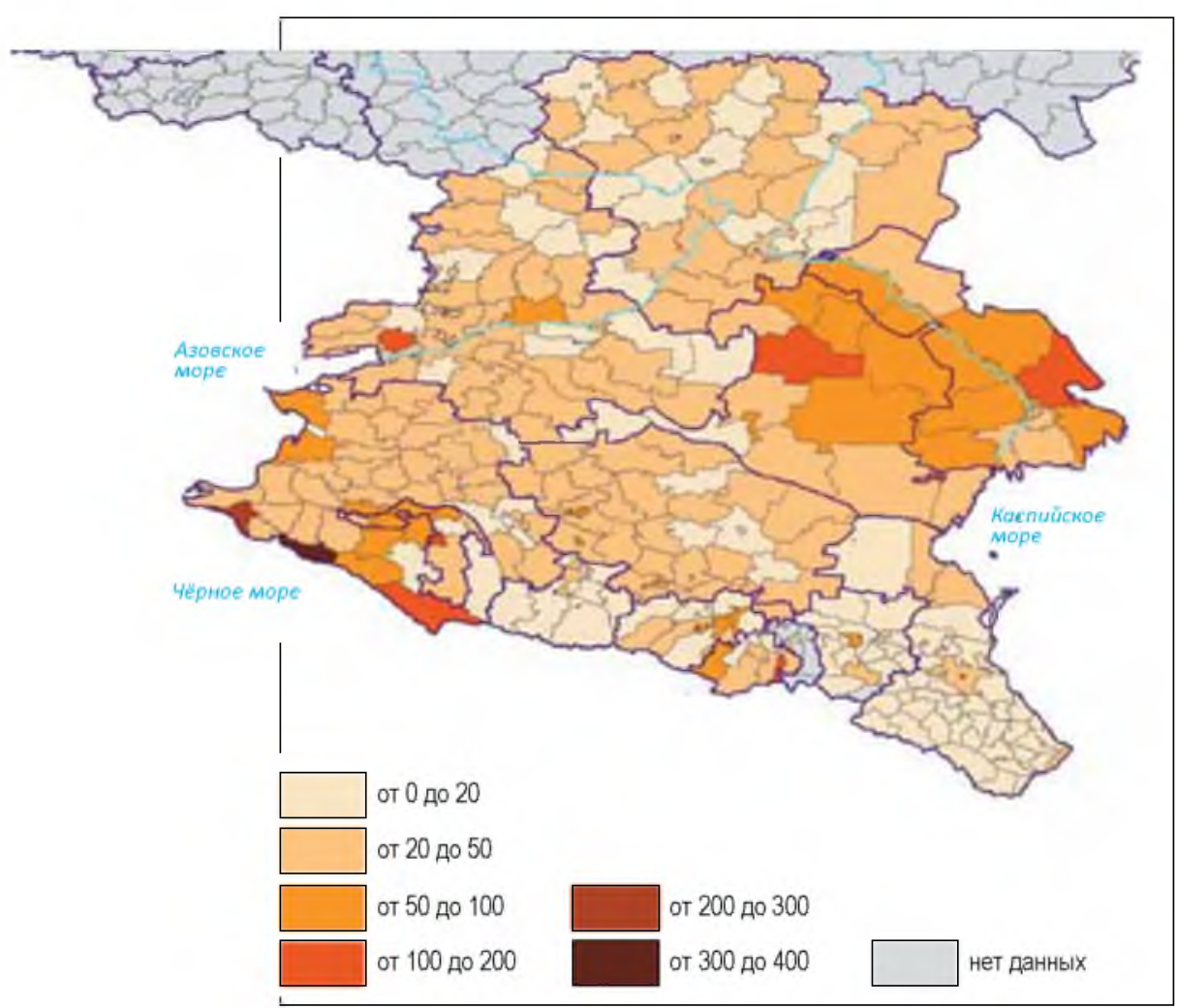

Рис. 2. Число мест в объектах общественного питания на 1000 человек населения, 2017 г.

Fig. 2 The number of places in public catering facilities per 1000 population, 2017.

и Республикой Калмыкия по данному показателю достигает 17 раз. Проведенный на базе ГИС-технологий анализ плотности автомобильных дорог на муниципальном уровне также выявил недостаточный уровень транспортной освоенности восточных районов Ростовской области, Республики Калмыкия, Астраханской, Волгоградской областей, Ставропольского края, что, несомненно, является ключевым ограничителем развития туризма на этих территориях (рис. 3).

Туризм в регионе зависит и от уровня развития воздушного транспорта [5;8;9]. На Юге России функционируют 15 аэропортов, которые в 2018 г. обслужили 22,7 млн пассажиров. Наибольшую долю в суммарном пассажиропотоке Юга имеют аэропорты Краснодарского края: Сочи (6,3 млн чел), Краснодар (4,2 млн чел), Анапа (1,5 млн чел.), а также аэропорт Ростова-на-Дону (3,2 млн чел) и Минеральных Вод (2,4 млн) (табл. 3). 


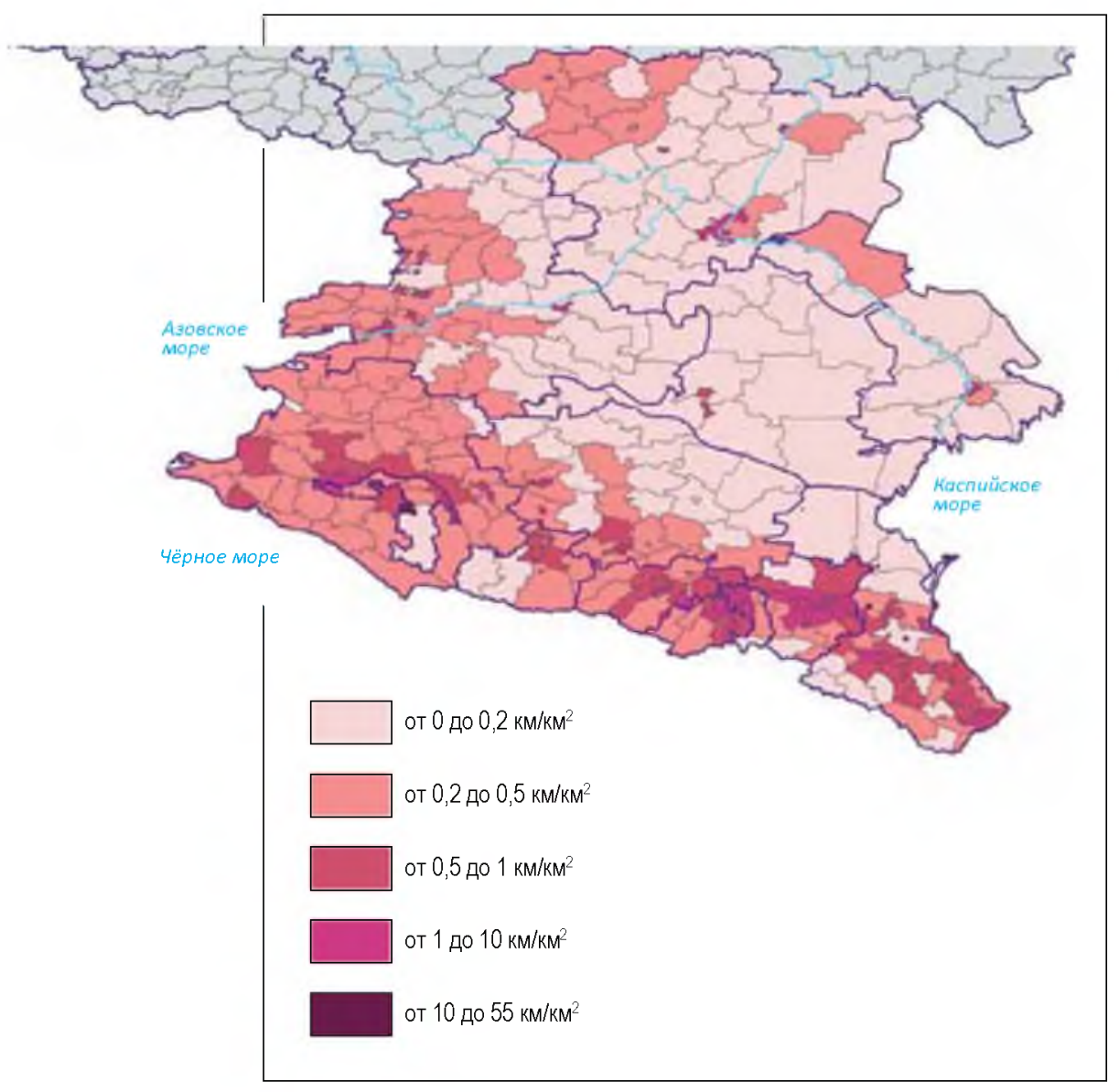

Рис. 3. Плотность автодорог общего пользования местного значения, находящихся в собственности муниципальных образований, 2018 г.

Fig. 3 The density of public roads of local importance owned by municipalities, 2018

Вместе с тем фокусом транспортной системы Юга России без сомнения можно считать город Сочи, по направлению к которому происходит стягивание и концентрация всех транспортных потоков. Проведенный анализ свидетельствует, что значимая «сочинская» составляющая в авиасообщение характерна для большинства аэропортов Юга России. В 2019 г. авиационные рейсы из Краснодара в Сочи осуществляются - 21 раз в неделю, из Волгограда - 9, из Ростова-на-Дону - 7 и т.д. Исключение составляют лишь Махачкала, Грозный и Анапа, авиасообщение с аэропортами которых в Сочи отсутствует.

В преддверии Олимпийских игр 2014 г. морской порт Сочи был реконструирован для приема большого числа круизных лайнеров. Пропускная спо- 
Таблица 3.

НЕКОТОРЫЕ ХАРАКТЕРИСТИКИ ТРАНСПОРТНОЙ ИНФРАСТРУКТУРЫ ЮГА РОССИИ, 2018 г.

Table 3. Some characteristics of the transport infrastructure of the South of Russia, 2018

\begin{tabular}{|c|c|c|c|}
\hline & $\begin{array}{l}\text { Плотность } \\
\text { железнодорожных } \\
\text { путей, } \\
\text { км путей на } 1000 \text { км² } \\
\text { территории }\end{array}$ & $\begin{array}{l}\text { Плотность автомобильных } \\
\text { дорог общего пользования } \\
\text { с твердым покрытием, } \\
\text { км путей на } 1000 \text { км² }^{2} \\
\text { территории }\end{array}$ & $\begin{array}{l}\text { Суммарный } \\
\text { пассажирооборот } \\
\text { аэропортов } \\
\text { региона, } \\
\text { чел. }\end{array}$ \\
\hline Юг России & 14,1 & 406 & 22680801 \\
\hline $\begin{array}{l}\text { Республика } \\
\text { Адыгея }\end{array}$ & 20,5 & 569,5 & 0 \\
\hline $\begin{array}{l}\text { Республика } \\
\text { Калмыкия }\end{array}$ & 2,2 & 49,2 & 10898 \\
\hline $\begin{array}{l}\text { Краснодарский } \\
\text { край }\end{array}$ & 28,3 & 463,1 & 12285804 \\
\hline $\begin{array}{l}\text { Астраханская } \\
\text { область }\end{array}$ & 12,9 & 88,5 & 597038 \\
\hline $\begin{array}{l}\text { Волгоградская } \\
\text { область }\end{array}$ & 14,3 & 143,5 & 1142878 \\
\hline $\begin{array}{l}\text { Ростовская } \\
\text { область }\end{array}$ & 18,9 & 262,9 & 3236000 \\
\hline $\begin{array}{l}\text { Республика } \\
\text { Дагестан }\end{array}$ & 10,1 & 410,3 & 1295353 \\
\hline $\begin{array}{l}\text { Республика } \\
\text { Ингушетия }\end{array}$ & 10,8 & 838,3 & 270096 \\
\hline $\begin{array}{l}\text { Кабардино- } \\
\text { Балкарская } \\
\text { Республика }\end{array}$ & 10,6 & 574,8 & 135000 \\
\hline $\begin{array}{l}\text { Карачаево- } \\
\text { Черкесская } \\
\text { Республика }\end{array}$ & 3,6 & 346,3 & 0 \\
\hline $\begin{array}{l}\text { Республика } \\
\text { Северная } \\
\text { Осетия - } \\
\text { Алания }\end{array}$ & 18,0 & 695,3 & 448000 \\
\hline $\begin{array}{l}\text { Чеченская } \\
\text { Республика }\end{array}$ & 19,5 & 573,4 & 458000 \\
\hline $\begin{array}{l}\text { Ставропольский } \\
\text { край }\end{array}$ & 13,9 & 271,6 & 2801734 \\
\hline
\end{tabular}


собность пассажирского терминала Сочи составляет 1,6 млн пассажиров в год. Но в связи с введением антироссийских санкций в настояшее время Сочи исключен из маршрутов ведущих круизных компаний. В 2016 г. его посетили всего четыре лайнера с 1194 пассажирами, в то время как в 2014 г. их было 63. В 2017 г. компания «Черноморские круизы» начала выполнять круизы из Сочи в Крым на лайнере «Князь Владимир».

В целях становления конкурентоспособных направлений туристского бизнеса в регионах Юга России необходимо осуществлять инвестиционные проекты, в том числе по развитию транспортной инфраструктуры.

\section{Выводы}

Формирование адекватной современным мировым стандартам высокоразвитой туристкой инфраструктуры - один из важнейших приоритетов развития экономики Юга России, обладающего уникальными в масштабах страны природными туристскими ресурсами, дополненными значительным культурно-историческим потенциалом.

Проведённое исследование позволяет идентифицировать основные детерминанты развития туристской инфраструктуры, присущие регионам Юга, а именно:

развитие приморских территорий как «полюсов роста»;

очаговый характер локализация объектов размещения и питания на горных территориях;

вовлечение в рекреационное использование территории Волго-Ахтубинской поймы, приоритетным направлением развития которой является охота и рыболовство;

неравномерность в транспортном освоении восточных и юго-западных регионов южнороссийского макрорегиона.

Рукопись поступила в редакцию 30.05 .2019 , принята к публикации 02.09.2019

\section{Библиографический} список

1. Атлас социально-экономического развития Юга России / под ред. А.Г. Дружинина. М.: Вузовская книга, 2011. 144 с.

2. Дружинин А.Г. Юг России конца $X X$ - начала $X X I$ в. (экономикогеографические аспект). Ростов н/Д: Изд-во Рост.ун-та, 2005. $284 \mathrm{c}$.

3. Федеральная службагосударственной статистики [Электронный 
ресурc]: официальный сайт. URL: http://gks.ru (дата обращения: 02.09.2019).

4. Шмыткова А.В. Основные тенденции развития средств размещения в России // Вестник Национальной академии туризма. 2017. № 1. C. 24-27.

5. Bieger T, Wittmer A. 2006. Air transport and tourism- perspectives and challenges for destinations, airlines and governments. Journal of Air Transport Management 12: 40-46.

6. Čuka P., Dorocki S., Rachwał T. Development of tourism infrastructure in the regions of Central and Eastern Europe. Conference: Innovation Vision 2020: from Regional Development Sustainability to Global Economic Growth, At Amsterdam, Netherlands, Volume: 25.

7. Dana, L.-P., Gurau, C., \& Lasch, F. 2014. Entrepreneurship, tourism and regional development: $A$ tale of two villages. Entrepreneurship and Regional Development, 26(3-4), 357-374.

8. Halsall D. 1998. Transport for tourism and recreation. In Modern Transport Geography, 2nd edn, Hoyle BS, Knowles RD (eds). Belhaven Press: London and New York.

9. Henderson J. 2008. Transport and tourism destination development: an Indonesian perspective. Tourism and Hospitality Research 9(3): 199-200.

10. Keller P. 2001. The Close Relationship between Air Transport and Tourism. In World Tourism Organization Seminar Proceedings. World Tourism Organization Publications: Madeira, Portugal.

11. Kozak, M. 2006. Konkurencyjność turystyczna polskich regionów, Studia Regionalne i Lokalne, 3(25), 49-65.

\section{References}

1. Atlas of socio-economic development of the South of Russia / ed. A.G. Druzhinin. M.: University Book, 2011. 144 p. (in Russ).

2. Druzhinin A.G. South of Russia at the end of the $X X$ - beginning of the $X X \mid$ century. (economic and geographical aspect). Rostov $n / D$ : Publishing house Rost. un-ta, 2005. 284 p. (in Russ)

3. Federal State Statistics Service [Electronic resource]: official site. URL: http://gks.ru (accessed date: September 2, 2019). (in Russ).

4. Shmytkova A.V. The main trends in the development of accommodation establishments in Russia // Bulletin of the National Academy of Tourism. 2017. No. 1. P. 24-27 (in Russ).

5. Bieger T, Wittmer A. 2006. Air transport and tourism- perspectives and challenges for destinations, airlines and governments. Journal of Air Transport Management 12: 40-46.

6. Čuka P., Dorocki S., Rachwał T. Development of tourism infrastructure in the regions of Central and Eastern Europe. Conference: Innovation Vision 2020: from Regional Development Sustainability to Global Economic Growth, At Amsterdam, Netherlands, Volume: 25.

7. Dana, L.-P., Gurau, C., \& Lasch, F. 2014. Entrepreneurship, tourism and regional development: A tale of two villages, Entrepreneurship and Regional Development, 26 (3-4), 357-374. 
8. Halsall D. 1998. Transport for tourism and recreation. In Modern Transport Geography, 2nd edn, Hoyle BS, Knowles RD (eds). Belhaven Press: London and New York.

9. Henderson J. 2008. Transport and tourism destination development: an Indonesian perspective. Tourism and Hospitality Research 9(3): 199-200.

10. Keller P. 2001. The Close Relationship between Air Transport and Tourism. In World Tourism Organization Seminar Proceedings. World Tourism Organization Publications: Madeira, Portugal.

11. Kozak, M. 2006. Konkurencyjność turystyczna polskich regionów, Studia Regionalne i Lokalne, 3(25), 49-65.

\section{6 авторах}

Ивлиева Ольга Васильевна, доктор географических наук, профессор кафедры туризма Южного федерального университета, ivlieva.o@ mail. ru, тел. +79185813297 .

Researcher ID D-2227-2019, Scopus ID 6507384454.

Шмыткова Анна Валериевна, старший преподаватель кафедры туризма Южного федерального университета, annav1109@mail.ru, тел. +79508432399 .

Ivlieva Olga Vasilievna, Doctor of Geographical Sciences, Professor, Department of Tourism, Southern Federal University, ivlieva.o@mail. ru, tel. +79185813297 .

Researcher ID D-2227-2019, Scopus ID 6507384454.

Shmytkova Anna Valerievna, Senior Lecturer, Department of Tourism, Southern Federal University, annav1109@mail.ru, tel. +7 9508432399. 